Hydrol. Earth Syst. Sci., 14, 557-571, 2010

www.hydrol-earth-syst-sci.net/14/557/2010/

(C) Author(s) 2010. This work is distributed under

the Creative Commons Attribution 3.0 License.

\title{
Frozen soil parameterization in a distributed biosphere hydrological model
}

\author{
L. Wang ${ }^{1}$, T. Koike ${ }^{1}$, K. Yang ${ }^{2}$, R. Jin ${ }^{3}$, and H. Li ${ }^{3}$ \\ ${ }^{1}$ Dept. of Civil Engineering, the University of Tokyo, Tokyo, Japan \\ ${ }^{2}$ Lab. of Tibetan Environment Changes and Land Surface Processes, Institute of Tibetan Plateau Research, Chinese Academy \\ of Sciences, Beijing, China \\ ${ }^{3}$ Cold and Arid Regions Environmental and Engineering Research Institute, Chinese Academy of Sciences, Lanzhou, China
}

Received: 26 October 2009 - Published in Hydrol. Earth Syst. Sci. Discuss.: 9 November 2009

Revised: 8 March 2010 - Accepted: 17 March 2010 - Published: 23 March 2010

\begin{abstract}
In this study, a frozen soil parameterization has been modified and incorporated into a distributed biosphere hydrological model (WEB-DHM). The WEB-DHM with the frozen scheme was then rigorously evaluated in a small cold area, the Binngou watershed, against the in-situ observations from the WATER (Watershed Allied Telemetry Experimental Research). First, by using the original WEB-DHM without the frozen scheme, the land surface parameters and two van Genuchten parameters were optimized using the observed surface radiation fluxes and the soil moistures at upper layers (5, 10 and $20 \mathrm{~cm}$ depths) at the DY station in July. Second, by using the WEB-DHM with the frozen scheme, two frozen soil parameters were calibrated using the observed soil temperature at $5 \mathrm{~cm}$ depth at the DY station from 21 November 2007 to 20 April 2008; while the other soil hydraulic parameters were optimized by the calibration of the discharges at the basin outlet in July and August that covers the annual largest flood peak in 2008. With these calibrated parameters, the WEB-DHM with the frozen scheme was then used for a yearlong validation from 21 November 2007 to 20 November 2008. Results showed that the WEB-DHM with the frozen scheme has given much better performance than the WEBDHM without the frozen scheme, in the simulations of soil moisture profile at the cold regions catchment and the discharges at the basin outlet in the yearlong simulation.
\end{abstract}

Correspondence to: L. Wang (wang@hydra.t.u-tokyo.ac.jp)

\section{Introduction}

Frozen soil (comprising permafrost and seasonally-frozen soil) process is critically important in the land surface hydrology of cold regions, since the freeze-thaw cycle significantly modulates the soil hydraulic and thermal characteristics that directly affect the water and energy cycles in the soil-vegetation-atmosphere transfer (SVAT) system.

At present, the improved modeling of the frozen soil process in a land surface scheme has been recognized an indispensable task for more reliable estimates of soil moisture and temperature profiles, particularly in the winter of Northern Hemisphere. The Project for Intercomparison of Land surface Parameterization Schemes phase 2(d) (PILPS 2(d)) has shown that the models with a frozen soil parameterization generally simulated realistic soil temperature during winter than those without a frozen scheme (Luo et al., 2003). Up to now, many studies have made efforts on improving the frozen soil parameterization in land surface modeling (e.g., Bonan et al., 1996; Slater et al., 1998; Koren et al., 1999; Smirnova et al., 2000; Li and Koike, 2003; Poutou et al., 2004; Woo et al., 2004; Niu and Yang, 2006; Zhang et al., 2007; Nicolsky et al., 2007; Luo et al., 2009).

By contrast, the frozen soil process is often inadequately represented or even neglected in most distributed hydrological models for basin-scale simulations, with only very few exceptions (e.g., Cherkauer and Lettenmaier; 1999; Zhang et al., 2000; Stocker-Mittaz et al., 2002; Tian et al., 2006; Mou et al., 2008; Ye et al., 2009). In fact, the representations of the frozen soil process can be indispensable in distributed hydrological modeling for the understanding of the water and energy cycles in some Northern-Hemisphere

Published by Copernicus Publications on behalf of the European Geosciences Union. 


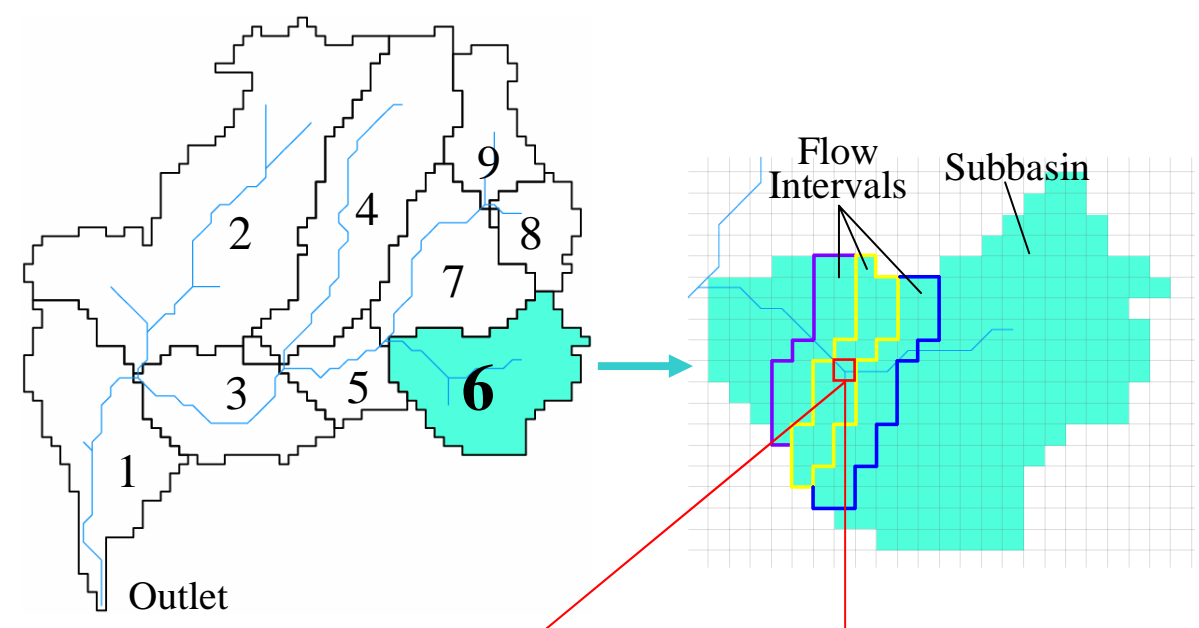

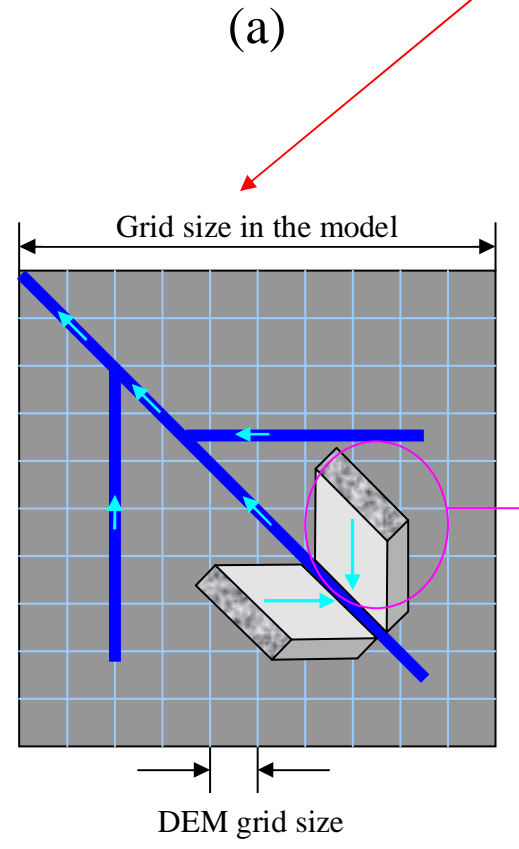

(c) (b)

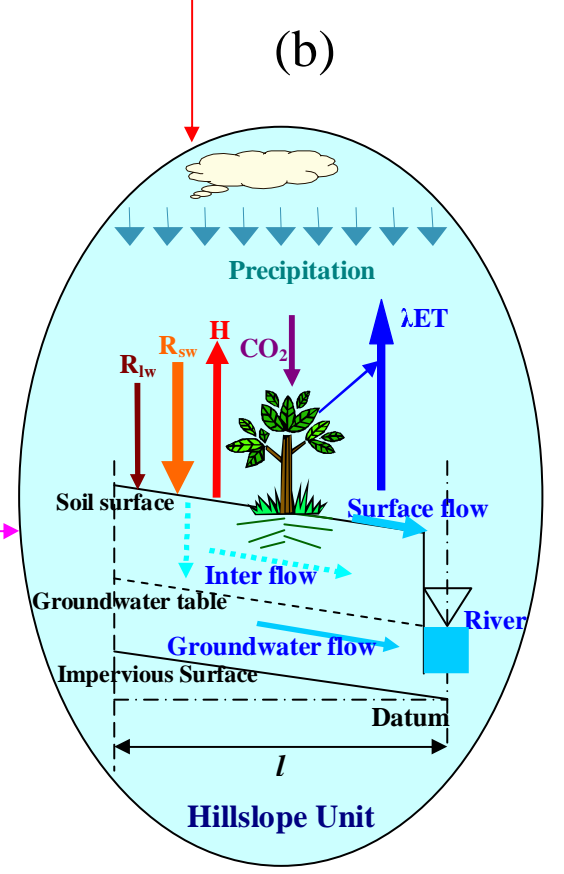

(d)

Fig. 1. Overall structure of WEB-DHM: (a) division from basin to sub-basins, (b) subdivision from sub-basin to flow intervals comprising several model grids, (c) discretization from a model grid to a number of geometrically symmetrical hillslopes, and (d) description of the water moisture transfer from atmosphere to river. Where $R_{\mathrm{sw}}$ and $R_{\mathrm{lw}}$ are downward solar radiation and longwave radiation, respectively, $H$ is the sensible heat flux, and $\lambda$ is the latent heat of vaporization. Here, the land surface submodel is used to describe the transfer of the turbulent fluxes (energy, water, and $\mathrm{CO}_{2}$ ) between atmosphere and ground surface for each model grid; while the hydrological submodel simulates both surface and subsurface runoff using grid-hillslope discretization, and then simulates flow routing in the river network.

river basins, because many large rivers in Northern Hemisphere (e.g., the Yellow River (see Tang et al., 2008) and the Heihe River (see Gao et al., 2008)) originate from high and cold mountain regions. As a result, the hydrological simulations in the upper cold subbasins of these river basins with a spatially-distributed manner become crucial for improving integrated water resources management.

This study aims at improving the performance of a distributed biosphere hydrological model (WEB-DHM; Wang et al., 2009a, b) in the simulations of the frozen soil process, which has been formulated in a previous study ( $\mathrm{Li}$ and Koike, 2003). This frozen soil scheme will be modified and incorporated into the WEB-DHM for better descriptions of the frozen soil process. By using yearlong continuous observations (soil moisture, soil temperature, and discharge) from the cold region hydrology experiment of WATER (Watershed Allied Telemetry Experimental Research; Li et al., 2008, 2009), the newly-developed WEB-DHM with 
the revised frozen scheme has been rigorously evaluated in a small cold river basin (Binggou) at the upper area of the Heihe River.

\section{Model description}

The WEB-DHM (Water and Energy Budget-based Distributed Hydrological Model) was a distributed biosphere hydrological model, which can give consistent descriptions of water, energy and $\mathrm{CO}_{2}$ fluxes at a basin scale (see Fig. 1). It can efficiently simulate hydrological processes of largescale river basins while incorporating subgrid topography (see Wang et al., 2009a).

In the study, a new version of the WEB-DHM has been developed by modifying and incorporating a frozen soil parameterization ( $\mathrm{Li}$ and Koike, 2003). First, the original WEBDHM is briefly reviewed in Sect. 2.1. Details about the hydrological submodel were discussed in Wang et al. (2009a); while the formulations of the land surface submodel can be found in Sellers et al. (1996a). Second, the frozen soil parameterization in WEB-DHM is presented in detail.

\subsection{Review of the original WEB-DHM}

\subsubsection{General model structure}

As illustrated in Fig. 1, the general model structure can be described as follows:

1. A digital elevation model (DEM) is used to define the target basin, which is then divided into sub-basins (see Fig. 1a). Within a given sub-basin, a number of flow intervals are specified to represent time lags and the accumulating processes in the river network. Each flow interval includes several model grids (see Fig. 1b).

2. For each model grid with one combination of land use type and soil type, the land surface submodel independently calculates turbulent fluxes between the atmosphere and land surface (see Fig. $1 \mathrm{~b}$ and $\mathrm{d}$ ). The vertical distributions of water for all the model grids, such as ground interception storage and soil moisture profile, can be obtained through this biophysical process.

3. Each model grid is subdivided into a number of geometrically symmetrical hillslopes (see Fig. 1c). A hillslope with unit length is called a basic hydrological unit (BHU) of the WEB-DHM. For each BHU, the hydrological submodel is used to simulate lateral water redistributions and calculate runoff comprised of overland, lateral subsurface and groundwater flows (see Fig. 1c and d). Overland flow is described by Manning's equation, and lateral subsurface flow and groundwater discharge are simulated using Darcy's law (Wang et al., 2009a). The runoff for a model grid is the total response of all BHUs within it.
4. For simplicity, the streams located in one flow interval are combined into a single virtual channel. All the flow intervals are linked by the river network generated from the DEM. All runoff from the model grids in the given flow interval is accumulated into the virtual channel and led to the outlet of the river basin. The flow routing of the entire river network in the basin is modeled using the kinematic wave approach.

\subsubsection{Soil model}

Two different soil subdivision schemes are used in describing land surface processes and hydrological processes.

In the calculation of land surface processes, the three-layer soil structure for the unsaturated zone is the same as that in SiB2. The depth of the first layer $\left(D_{1}\right)$ is defined as $5 \mathrm{~cm}$, while the root depth $\left(D_{1}+D_{2}\right)$ could be defined according to vegetation type by SiB2 default. The thickness of the deep soil zone $\left(D_{3}\right)$ changes with fluctuation of the water table and is equal to the depth of the groundwater level minus the thickness of the upper two layers.

In the simulation of soil water flow, a multiple-sublayer soil structure is employed to describe the unsaturated zone. In the model, the non-uniform vertical distribution is represented using an assumption of exponentially decreasing hydraulic conductivity with increasing soil depth given by $k_{z}=k_{\text {surface }} \cdot \exp (-f \cdot z)$ (Beven, 1982; Cabral et al., 1992; Robinson and Sivapalan, 1996), where $k_{\text {surface }}$ and $k_{z}$ are hydraulic conductivities at the soil surface and depth $z$, and $f$ is a decay factor. The surface layer with a depth $D_{1}$ is kept as the first layer. The root zone and deep soil zone are uniformly subdivided into several sublayers. As shown in Fig. 2, the multiple-sublayer structure is employed to calculate vertical interlayer flows and lateral runoff. The vertical interlayer flows in the unsaturated zone are described using a one-dimensional Richards equation (see Wang et al., 2009a).

In this soil model, the van Genuchten equation (van Genuchten, 1980) is used as the soil hydraulic function.

\subsection{Frozen soil parameterization}

\subsubsection{Soil hydraulic properties}

Total volumetric water content of the $j$-th soil layer $\left(\theta_{j}\right.$; $\mathrm{m}^{3} \mathrm{~m}^{-3}$ ) is defined as

$\theta_{j}=\theta_{\text {liq }, j}+\theta_{\text {ice, } j} \frac{\rho_{\text {ice }}}{\rho_{\text {liq }}}$.

Where, $\theta_{\text {liq, } j}$ and $\theta_{\text {ice, } j}$ are the liquid water content and the ice content $\left(\mathrm{m}^{3} \mathrm{~m}^{-3}\right)$ of the $j$-th soil layer; $\rho_{\text {ice }}$ and $\rho_{\text {liq }}$ are the density $\left(\mathrm{kg} \mathrm{m}^{-3}\right)$ of ice and liquid water, respectively.

For the $j$-th soil layer, the unfrozen water content $\left(\theta_{\text {liq }, j}\right)$ is assumed as a simple power function of soil temperature $\left(T_{\text {soil }, j}\right)$ (see Nakano et al., 1982; Romanovsky and Osterkamp, 2000; Li and Koike, 2003)

$\theta_{\text {liq }, j}=a\left(T_{f}-T_{\text {soil }, j}\right)^{b}$, 


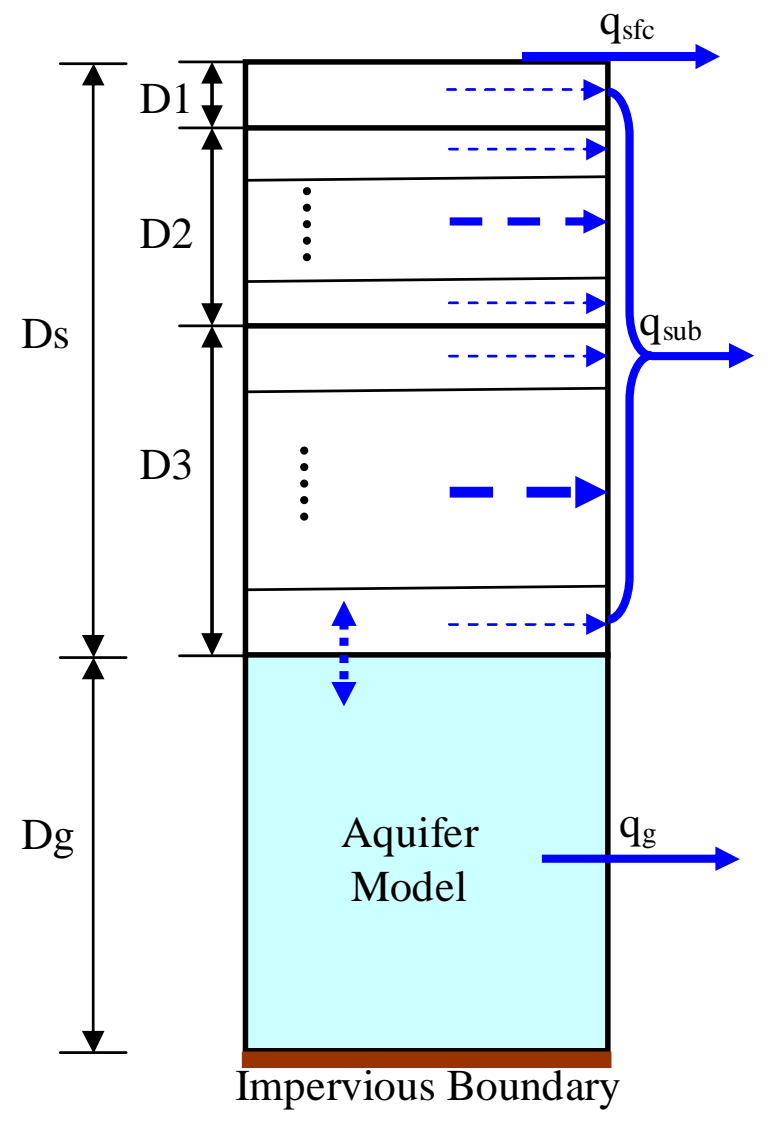

Fig. 2. Soil model of the WEB-DHM. Two different soil subdivision schemes are used for describing land surface and hydrological processes, respectively. The three-layer soil structure used in SiB2 is retained to represent the unsaturated zone in the calculations of land surface processes. The unsaturated zone is divided into multiple sublayers when simulating water flows within it and water exchanges with groundwater aquifer.

where, $a$ and $b$ are two empirical coefficients associated with soil type. Then the changing rate of liquid soil moisture (or ice) to soil temperature can be derived as

$$
\frac{\partial \theta_{\text {liq }, j}}{\partial T_{\text {soil }, j}}=-\frac{\rho_{\text {ice }}}{\rho_{\text {liq }}} \frac{\partial \theta_{\text {ice }, j}}{\partial T_{\text {soil }, j}}=(-a b)\left(T_{f}-T_{\text {soil }, j}\right)^{b-1} .
$$

The soil hydraulic conductivity $K_{j}$ and soil matric potential $\psi_{j}$ at the $j$-th soil layer in the unsaturated zone are described using a modified version of the van Genuchten's equation (van Genuchten, 1980):

$$
\begin{aligned}
K_{j}= & f_{\text {ice }, j} K_{\mathrm{sat}, j}\left(\frac{\theta_{\mathrm{liq}, j}-\theta_{r}}{\theta_{\mathrm{s}}-\theta_{\mathrm{r}}}\right)^{1 / 2} \\
& {\left[1-\left(1-\left(\frac{\theta_{\mathrm{liq}, j}-\theta_{\mathrm{r}}}{\theta_{\mathrm{s}}-\theta_{\mathrm{r}}}\right)^{-1 / m}\right)^{m}\right]^{2}, } \\
\psi_{j}= & \frac{1}{\alpha}\left[\left(\frac{\theta_{\mathrm{liq}, j}-\theta_{\mathrm{r}}}{\left(\theta_{\mathrm{s}}-\theta_{\mathrm{ice}, j}\right)-\theta_{\mathrm{r}}}\right)^{-1 / m}-1\right]^{1 / n} .
\end{aligned}
$$

Where, $\theta_{\mathrm{s}}$ is porosity and $\theta_{\mathrm{r}}$ is residual water content; $\alpha, n$ are empirical parameters in van Genuchten's equation with $m=1-1 / n$; the hydraulic conductivity reduction factor for the $j$-th soil layer $\left(f_{\text {ice, }, j}\right)$ is defined as a function of soil temperature at that layer

$f_{\text {ice }, j}=\exp \left(-10 \cdot\left(T_{f}-T_{\text {soil }, j}\right)\right)$ and $0.05 \leq f_{\text {ice }, j} \leq 1$;

and $K_{\mathrm{sat}, j}$ is the saturated hydraulic conductivity at depth $z$ (defined as the location of the center of the $j$-th soil layer), which is measured downward in a direction normal to the soil surface $(m) . K_{\mathrm{sat}, j}$ is represented using the assumption of an exponential increase in hydraulic conductivity with increasing soil depth (that is the decay factor $f<0$ ).

Similar to $K_{j}$, the groundwater hydraulic conductivity $K_{\mathrm{G}}$ is also formulated considering the frozen soil effect

$K_{\mathrm{G}}=f_{\text {ice, } \mathrm{G}} K_{\mathrm{G} 0}$.

Where, the reduction factor $f_{\text {ice, } \mathrm{G}}\left(=\exp \left(-10 \cdot\left(T_{f}-T_{\mathrm{B}}\right)\right)\right.$ and $\left.0.05 \leq f_{\text {ice, }, \mathrm{G}} \leq 1\right)$ is expressed as a function of the temperature of the bottom soil layer $\left(T_{\mathrm{B}}\right) ; K_{\mathrm{G} 0}$ is the groundwater hydraulic conductivity without considering frozen soil $\left(\mathrm{m} \mathrm{s}^{-1}\right)$.

\subsubsection{Soil thermal properties}

For the soil temperatures at the ground surface and the deep soil, the force-restore model (Deardorff, 1977) of the heat balance in the soil surface is kept, but the effective heat capacities of the soil surface and the snow-free soil are modified to represent the latent heat of fusion or the change of soil thermal conductivity

$C_{\mathrm{g}} \frac{\partial T_{\mathrm{g}}}{\partial t}=R n_{\mathrm{g}}-H_{\mathrm{g}}-\lambda E_{\mathrm{g}}-\frac{2 \pi C_{\mathrm{d}}}{\tau_{\mathrm{d}}}\left(T_{\mathrm{g}}-T_{\mathrm{d}}\right)-\xi_{\mathrm{gs}}$,

$C_{\mathrm{d}} \frac{\partial T_{\mathrm{d}}}{\partial t}=\frac{1}{2(365 \pi)^{1 / 2}}\left(R n_{\mathrm{g}}-H_{\mathrm{g}}-\lambda E_{\mathrm{g}}\right)$,

where, $C_{\mathrm{g}}$ and $C_{\mathrm{d}}$ are the effective heat capacity $\left(\mathrm{J} \mathrm{m}^{-2} \mathrm{~K}^{-1}\right)$ for the soil surface and the snow-free soil; $T_{\mathrm{g}}$ and $T_{\mathrm{d}}$ are the temperatures for the soil surface and the deep soil, respectively $(\mathrm{K}) ; R n_{\mathrm{g}}$ is the absorbed net radiation by soil surface $\left(\mathrm{W} \mathrm{m}^{-2}\right) ; H_{\mathrm{g}}$ is the sensible heat flux from soil surface $\left(\mathrm{W} \mathrm{m}^{-2}\right) ; E_{\mathrm{g}}$ is the bare soil evaporation rate $\left(\mathrm{kg} \mathrm{m}^{-2} \mathrm{~s}^{-1}\right)$; $\lambda$ is the latent heat of vaporization $\left(\mathrm{J} \mathrm{kg}^{-1}\right) ; \tau_{\mathrm{d}}$ is daylength (s); $\xi_{\mathrm{gs}}$ is the energy transfer due to phase changes in snow on ground $\left(\mathrm{W} \mathrm{m}^{-2}\right)$.

The soil thermal conductivity $\left(H_{\mathrm{s}, \text { new }} ; \mathrm{W} \mathrm{m}^{-1} \mathrm{~K}^{-1}\right)$ is calculated following $\mathrm{Li}$ and Cheng (1995)

$$
\begin{aligned}
& H_{\mathrm{s}}=\left[\frac{1.5 \cdot\left(1-\theta_{\mathrm{s}}\right)+1.3 \theta_{1}}{0.75+0.65 \theta_{\mathrm{s}}-0.4 \theta_{1}}\right] 0.4186 \text {, } \\
& H_{\mathrm{s}, \text { new }}=\left\{\begin{array}{ll}
H_{\mathrm{s}}+\left(H_{\mathrm{s}, \max }-H_{\mathrm{s}}\right) \cdot \theta_{\mathrm{ice}, 1} \cdot\left(\rho_{\mathrm{ice}} / \rho_{\mathrm{liq}}\right) /\left(\theta_{1}-\theta_{\mathrm{liq}, \min }\right) & T_{\mathrm{g}} \leq T_{f} \\
H_{s} & T_{\mathrm{g}}>T_{f}
\end{array} .\right.
\end{aligned}
$$


Where, $H_{\mathrm{s}}$ is soil thermal conductivity without considering frozen soil; $H_{\mathrm{s}, \max }$ is the maximum heat conductivity after freezing; $\theta_{\text {liq,min }}$ is the minimum liquid water content after freezing. In the study, $\theta_{\text {liq, } \min }=0.05$; while $H_{\mathrm{s}, \max }=2.5$ considering the existence of gravels in the soil.

The new equations of $C_{\mathrm{d}}$ and $C_{\mathrm{g}}$ are described as follows

$C_{\mathrm{d}}=0.5\left(\frac{H_{\mathrm{s}, \text { new }} C_{\text {soil }} \cdot 86400}{\pi}\right)^{1 / 2}$.

$C_{\mathrm{g}}=\left\{\begin{array}{lr}d_{\mathrm{s}}\left(C_{\text {soil }}+\rho_{\mathrm{liq}} L_{f} \frac{\partial \theta_{\text {iq }}, 1}{\partial T_{\mathrm{g}}}\right)+\min \left[0.05,\left(M_{\mathrm{gw}}+M_{\mathrm{gs}}\right)\right] C_{\mathrm{w}} & T_{\mathrm{g}}<T_{f}-0.01 \\ d_{\mathrm{s}} C_{\text {soil }}+\min \left[0.05,\left(M_{\mathrm{gw}}+M_{\mathrm{gs}}\right)\right] C_{\mathrm{w}} & T_{f}-0.01 \leq T_{\mathrm{g}} \leq T_{f}, \\ C_{\mathrm{d}}+\min \left[0.05,\left(M_{\mathrm{gw}}+M_{\mathrm{gs}}\right)\right] C_{\mathrm{w}} & T_{\mathrm{g}}>T_{f}\end{array}\right.$

where $d_{\mathrm{s}}$ is the effective depth $(\mathrm{m})$ that feels the diurnal change of temperature (Stull, 1988); $C_{\text {soil }}$ is the volumetric heat capacity of soil $\left(\mathrm{J} \mathrm{m}^{-3} \mathrm{~K}^{-1}\right)$ and $C_{\text {soil }}=\left(0.5 \cdot\left(1-\theta_{\mathrm{s}}\right)+\theta_{\mathrm{liq}, 1}+0.175 \cdot \theta_{\text {ice }, 1}\right) \cdot 4.186 \times 10^{6} ;$ the $\rho_{\text {liq }} L_{f}\left(\partial \theta_{\text {liq }, 1} / \partial T_{\mathrm{g}}\right)$ represents the apparent heat capacity of soil freezing in the surface soil layer, and $\partial \theta_{\text {liq, } 1} / \partial T_{\mathrm{g}}=$ $(-a b)\left(T_{f}-T_{\mathrm{g}}\right)^{b-1} ; M_{\mathrm{gw}}$ is the soil interception of liquid water store (m); $C_{\mathrm{w}}$ is the volumetric heat capacity of water $\left(\mathrm{J} \mathrm{m}^{-3} \mathrm{~K}^{-1}\right)$. It should be mentioned that when the soil surface temperature is just below the freezing point, the phase changing rate $\partial \theta_{\mathrm{liq}, 1} / \partial T_{\mathrm{g}}$ reaches its maximum value, making the effective heat capacity a very large value and therefore hampering the heat transfer. In order to solve this problem, $C_{\mathrm{g}}=d_{\mathrm{s}} C_{\mathrm{soil}}+\min \left[0.05,\left(M_{\mathrm{gw}}+M_{\mathrm{gs}}\right)\right] C_{\mathrm{w}}$ is set for the transition zone from $T_{f}-0.01$ to $T_{f}$ in this study.

The depth of seasonal frost penetration is determined by the soil temperature profile, which is solved with Stefan solution (Yershov, 1990). The Stefan solution assumes a linear soil temperature profile in the frozen soil column, and for simplicity the soil temperature at $5 \mathrm{~cm}\left(T_{\text {soil, } D_{1}}\right)$ is assumed as

$$
T_{\text {soil }, D_{1}}=\eta T_{\mathrm{g}}+(1-\eta) T_{\mathrm{d}} .
$$

Where, $\eta$ is an empirical factor and $\eta=0.5$ is used in this study.

The frost and thaw depths $\left(\zeta_{\mathrm{f}}\right.$ and $\left.\zeta_{\mathrm{t}}\right)$ is simulated following $\mathrm{Li}$ and Cheng (1995), and can be expressed in equations of the approximation Stefan solution (The Institute of Geocryology, 1974; Li and Koike, 2003) as follows.

$\zeta_{\mathrm{f}}=\sqrt{\frac{2 \kappa_{\mathrm{f}} \tau_{\mathrm{h}} \sum_{i=1}^{t}\left(T_{\mathrm{f}}-T_{\mathrm{soil}, D_{1}}\right)}{L_{\mathrm{f}} \rho_{l} \theta},}$

$\zeta_{\mathrm{t}}=\sqrt{\frac{2 \kappa_{\mathrm{t}} \tau_{\mathrm{h}} \sum_{i=1}^{t}\left(T_{\mathrm{soil}, D_{1}}-T_{\mathrm{f}}\right)}{L_{\mathrm{f}} \rho_{i} \theta}}$, where, $\kappa_{\mathrm{f}}$, and $\kappa_{\mathrm{t}}$ are the thermal conductivity of freezing and thawing soils $\left(\mathrm{W} \mathrm{m}^{-1} \mathrm{~K}^{-1}\right)$, respectively; $\tau_{\mathrm{h}}$ is the time length (s) and $\tau_{\mathrm{h}}=3600 \mathrm{~s}$ in the study.

After determining the position of freezing front, the sublayer soil temperature in the root zone and deep soil are estimated by a simple function of frost depth.

If $z \leq \zeta_{\mathrm{f}}$, the soil temperature at a given depth $z$ is

$T_{\text {soil }, z}=T_{\mathrm{f}}+\left(T_{\text {soil }, D_{1}}-T_{\mathrm{f}}\right)\left(1-\frac{z}{\zeta_{\mathrm{f}}}\right) ;$

If $z>\zeta_{\mathrm{f}}$, the soil temperature at a given depth $z$ is

$T_{\text {soil }, z}=T_{\mathrm{f}}+\left(T_{\mathrm{d}}-T_{\mathrm{f}}\right)\left(\frac{z-\zeta_{\mathrm{f}}}{D_{\mathrm{s}}-\zeta_{\mathrm{f}}}\right)$,

where $D_{\mathrm{s}}$ is the top soil depth (see Fig. 2).

\section{Datasets for the study area}

The cold region hydrology experiment is one of key experiments within the Watershed Allied Telemetry Experimental Research (WATER; Li et al., 2008, 2009). The Binggou watershed (Fig. 3), located at $100^{\circ} 12^{\prime}-100^{\circ} 18^{\prime} \mathrm{E}$ and $38^{\circ} 1^{\prime}-$ $38^{\circ} 4^{\prime} \mathrm{N}$, is one of the three foci experimental areas where cold region hydrology experiments were carried out within the framework of the WATER.

The Binggou watershed, located in the upper reaches of the Heihe River Basin (Fig. 3), is a high mountain drainage system with an area of $30.48 \mathrm{~km}^{2}$. The elevation is from about 3440 to $4400 \mathrm{~m}$ (Fig. 3). The watershed has the obvious vertical-zonality natural landscape (Yang et al., 1992). In the altitude from 3440 to $4000 \mathrm{~m}$, there is mainly alpine meadow; while in the altitude from 3440 to $3700 \mathrm{~m}$, the shrubs and the fish-scale shape sod coexist. In the region above $4000 \mathrm{~m}$, there is mainly the non-vegetation's alpine desert, and the exposed decency rock debris quite grows having high water-permeability. The longterm mean annual temperature is about $-5.8^{\circ} \mathrm{C}$ in the mean altitude $(3900 \mathrm{~m})$ of the watershed (Yang et al., 1992). In the watershed, the permafrost distributes at the region higher than $4000 \mathrm{~m}$, with the air temperature lower than $0{ }^{\circ} \mathrm{C}$ in 9 months (September to next May); while the discontinuous permafrost dominates the region lower than $4000 \mathrm{~m}$, with the air temperature lower than $0^{\circ} \mathrm{C}$ in 7 months (October to next April) (Yang et al., 1993). The longterm mean annual precipitation is about $686 \mathrm{~mm}$, with about 74\% rainfall and 26\% snowfall (Zhang and Yang, 1991). The snowfall prevails from October to April; the rainfall concentrates on July and August; while sleet occurs in May, June and September (Yang et al., 1992). The mean depth of the seasonable snowpack is about $0.5 \mathrm{~m}$, with a maximum of $0.8-1.0 \mathrm{~m}$ (Yang et al., 1993).

The datasets of the Binggou Watershed, as used in WEBDHM, are as described below.

DEM and land use were provided by the WATER project (Li et al., 2008, 2009). The model simulation adopted a grid 


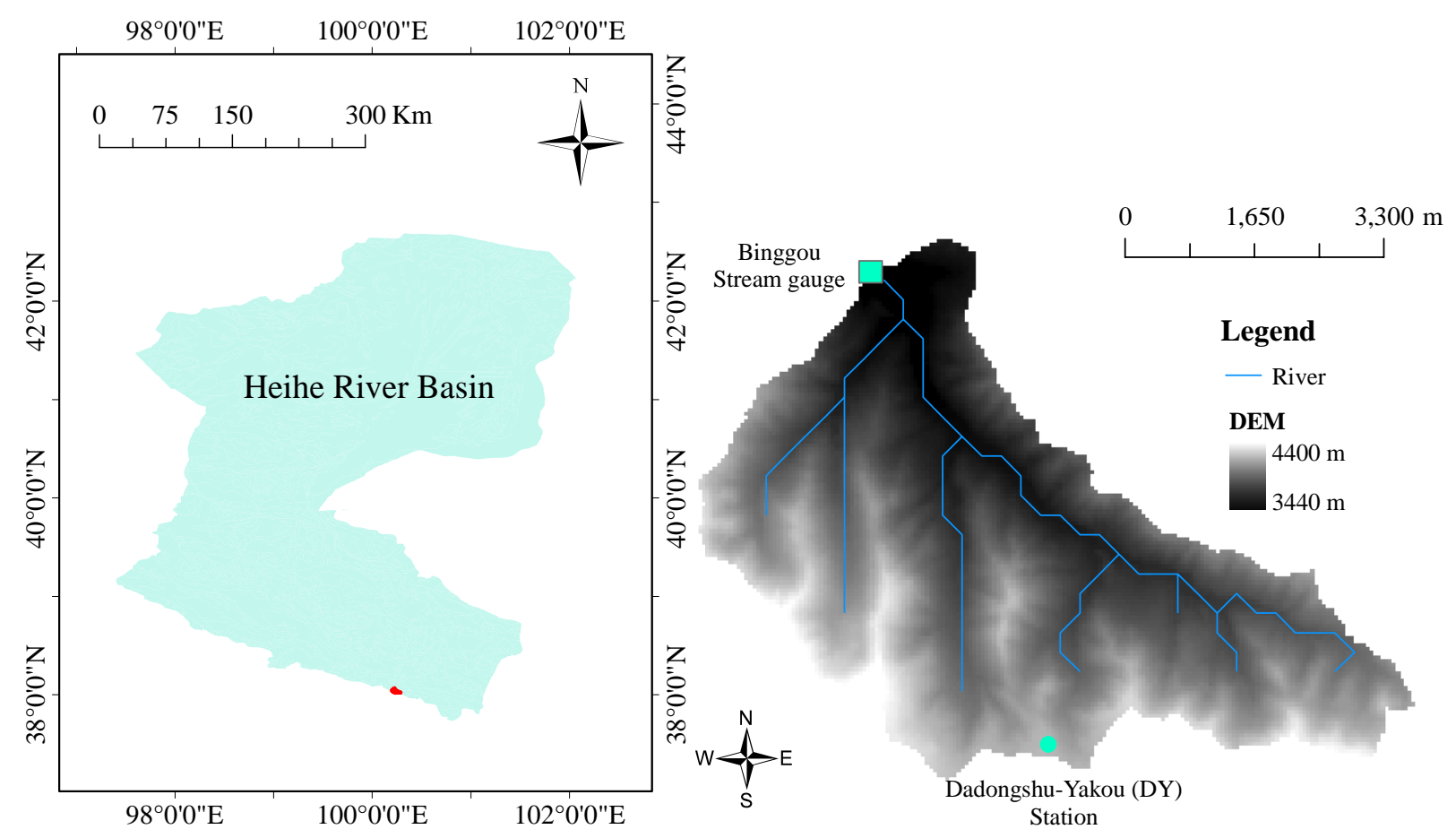

Fig. 3. The Binggou watershed.

size of $250 \mathrm{~m}$, and the subgrid topography was described by a $50 \mathrm{~m}$ resolution DEM. The land uses have been reclassified to $3 \mathrm{SiB} 2$ categories (Agriculture/C3 grassland, Dwarf trees and shrubs, and broadleaf shrubs with bare soil). In the Dadongshu-Yakou (DY) station (with the elevation of $4146.8 \mathrm{~m}$; see Fig. 3), surface meteorological variables, as well as soil moisture and soil temperature profiles were measured (with soil moisture and temperature sensors) continuously at the 10-min interval from 21 November 2007 to 20 November 2008. The precipitation, relative humidity, air temperature, and wind speed, as well as air pressure, downward longwave and shortwave radiation, obtained from the station were summated into the hourly time series and taken as the forcing data for the whole watershed because the basin is small and distributed data is not available. The surface air temperature inputs were modified with a lapse rate of $6.5 \mathrm{~K} \mathrm{~km}^{-1}$, considering the elevation differences between the model grids and the DY station. However, the altitudinal effect on relative humidity was assumed negligible. At the basin outlet, the Binggou stream gauge was newly built in 2008 and discharge data has been obtained from 17 January to 20 November 2008 for model evaluation, with the frequency of several times a day. The method of discharge measurements is briefly described as follows. First, a rectangle cross section was built using concrete at the selected point. Second, the water depth (which was used to derive the area of the cross section) and the flow velocity at the cross section were measured by the local staff several times a day (not hourly). Third, the flow velocity and the area of the cross-section were used to calculate the discharge at the cross-section.

The dynamic vegetation parameters are Leaf Area Index (LAI) and the Fraction of Photosynthetically Active Radiation (FPAR) absorbed by the green vegetation canopy, and can be obtained from satellite data. Global LAI and FPAR MOD15_BU $1 \mathrm{~km}$ data sets (Myneni et al., 1997) were used in this study. These are 8-daily composites of MOD15A2 products and were obtained using the Warehouse Inventory Search Tool (WIST) of NASA.

All simulations were carried out with $250 \mathrm{~m}$ spatial resolution and hourly time step.

\section{Model evaluations at the Binggou watershed}

For the Binggou watershed, the hydrological processes are not only controlled by the hydro-meteorological conditions of the land surface, but also by the underlying frozen soil. The spring snowmelt occupies about $30 \%$ of the annual runoff; while the residual comes from rainfall and groundwater (Zhang and Yang, 1991). In the lower area of the watershed, soil starts thawing around April and stops by August; while in the upper regions, soil starts thawing around late May. In the watershed, the thickness of the active frozen soil layer is about $1.0-1.5 \mathrm{~m}$ in the lower regions, and is greater than $3.0 \mathrm{~m}$ in the upper mountain regions (Yang et al., 1993). 
In the early spring (April to May), with the increase of air temperature, snowmelt occurs from the lower regions to the mountain areas. However, during this period (April to May), the air temperature exceeds $0{ }^{\circ} \mathrm{C}$ only at noon, but drops to below $0{ }^{\circ} \mathrm{C}$ at night. Consequently, much of the snowmelt water freezes again at night before its departure from snowpack. Therefore, the snowmelt runoff in the early spring is small (around 15\% of annual runoff; Zhang and Yang, 1991). From May to June (late spring), the air temperature increases to above $0^{\circ} \mathrm{C}$ stably, and the snowmelt runoff becomes very large (greater than $25 \%$ of annual runoff; Zhang and Yang, 1991). This is also attributed to the little permeability of the underlying seasonal frozen soil layers which have thawed only in upper soil layers (Kane and Stein, 1983). In summer, snow and seasonal frozen soil layers disappear, and thus rainfall becomes the major source for river discharges. But the permanent frozen soil layers still exist, which prohibit the water infiltration to deeper layers. Heavy rainfall events in summer will usually result in severe flash floods in this watershed, along with landslides and debris flows (Yang et al., 1993).

\subsection{Model calibration}

The vegetation static parameters including morphological, optical and physiological properties were initially defined following Sellers et al. (1996b). In the summer 2008, by using the WEB-DHM without the frozen scheme, the land surface parameters were optimized using the observed radiation fluxes at the DY station in July; and then the two van Genuchten parameters ( $\alpha$ and $n$ ) were optimally obtained by the calibration of the July soil moistures at upper layers $(5,10$ and $20 \mathrm{~cm}$ depths) at the DY station. In the cold season from 21 November 2007 to 20 April 2008, by using the WEBDHM with the frozen scheme, the parameters ( $a$ and $b$ ) used in the frozen soil scheme were optimized through matching the simulated and observed soil temperatures at $5 \mathrm{~cm}$ depth $\left(T_{\text {soil }, D_{1}}\right)$. Third, by using the WEB-DHM with the frozen scheme, the other soil hydraulic parameters were optimally obtained by the calibration of the discharges at the basin outlet in July and August that covers the annual largest flood peak in 2008.

\subsubsection{Parameters optimized through the WEB-DHM without the frozen scheme}

First, the land surface parameters were optimized using the observed surface radiation fluxes at the DY station in July. For the DY station, land is covered by the SiB2 biome 9 ("Agriculture/C3 grassland"). The canopy cover fraction, the height of canopy top, and the height of canopy bottom, as well as the root depth $(D r)$, the top soil depth $(D s)$, and the ground roughness length $\left(z_{\mathrm{s}}\right)$ have been designed as $0.2,0.05 \mathrm{~m}, 0.005 \mathrm{~m}, 0.25 \mathrm{~m}, 1.25 \mathrm{~m}$, and $0.001 \mathrm{~m}$ according to the field obervations in $\mathrm{Li}$ et al. (2009). The soil re- flectance to visible radiation for the $\mathrm{SiB} 2$ biome 9 was optimized as 0.15 using observed upward shortwave radiation in July 2008; while the surface emissivity has been kept as 1.0 following Seller et al. (1996b). Other time-invariant vegetation parameters were set following Sellers et al. (1996b). Soil hydraulic properties have been kept equal to values derived from FAO (2003) during the calibration of land surface parameters.

Second, the two van Genuchten parameters ( $\alpha$ and $n$ ) were optimized by using the measured soil moistures at upper layers at the DY station. The porosity and the residual soil moisture were set as 0.585 and 0.017 according to the yearlong soil moisture measurements from 21 November 2007 to 20 November 2008 in the DY station. The van Genuchten parameters $\alpha$ and $n$ regulate the soil hydraulic function which controls the soil water transport. They were optimized as 0.1 and 2.1 , respectively, by comparing the simulated and observed soil moistures at the upper soil layers (5, 10, and $20 \mathrm{~cm}$ ) in July 2008 at the DY station; while keeping the original values of $K_{\text {surface }}$ obtained from FAO (2003).

\subsubsection{Parameters optimized through the WEB-DHM with the frozen scheme}

First, at the DY station, the frozen soil parameters ( $a$ and $b$ ) are optimized through matching the simulated and observed $T_{\text {soil, } D_{1}}$ in the cold season (from 21 November 2007 to 20 April 2008); while $d_{\mathrm{s}}$ is set as $0.6 \mathrm{~m}$, according to the measured winter soil temperature profiles at the DY station (Li et al., 2009).

Second, at the basin-scale, the other soil hydraulic parameters were further optimized to obtain good reproduction of the flood event that occurred at the Binggou stream gauge during the summer (July and August) of 2008. These parameters include the saturated hydraulic conductivity for soil surface $K_{\text {surface }}$, the soil anisotropy ratio anik, the groundwater hydraulic conductivity (without considering frozen soil) $K_{\mathrm{G} 0}$, and the hydraulic conductivity decay factor $f$. The optimization was done using a trial and error method by matching the simulated and observed flood peaks and tails. It should be mentioned that the assumption of an exponential increase in hydraulic conductivity with increasing soil depth is used in the WEB-DHM with the frozen scheme $(f<0)$.

The basin-averaged values of the land surface and soil hydraulic parameters, as well as the frozen soil parameters used in the Binggou watershed are listed in Table 1.

\subsubsection{Calibration results}

The bias error (BIAS) and root mean squared error (RMSE) are used as evaluation criterion for the simulated results, where BIAS and RMSE are defined as

$$
\mathrm{BIAS}=\sum_{i=1}^{N}\left(x_{\mathrm{si}}-x_{\mathrm{oi}}\right) / N,
$$


Table 1. Basin-averaged values of the parameters used in the Binggou watershed.

\begin{tabular}{|c|c|c|c|c|}
\hline Symbol & Parameters & Unit & Value & Source \\
\hline \multicolumn{5}{|c|}{ Land surface parameters } \\
\hline$z_{2}$ & Height of canopy top & $\mathrm{m}$ & 0.05 & Li et al. (2009) \\
\hline$z_{1}$ & Height of canopy bottom & $\mathrm{m}$ & 0.005 & Li et al. (2009) \\
\hline V & Canopy cover fraction & & 0.3 & Li et al. (2009) \\
\hline$\alpha_{\mathrm{s}, \mathrm{V}}$ & Soil reflectance to visible radiation & & 0.12 & Optimization \\
\hline$z_{\mathrm{s}}$ & Ground roughness length & $\mathrm{m}$ & 0.001 & Li et al. (2009) \\
\hline$D_{\mathrm{r}}$ & Root depth $\left(D_{1}+D_{2}\right)$ & $\mathrm{m}$ & 0.25 & Li et al. (2009) \\
\hline Ds & Top soil depth $\left(D_{1}+D_{2}+D_{3}\right)$ & $\mathrm{m}$ & 1.25 & Li et al. (2009) \\
\hline \multicolumn{5}{|c|}{ Soil hydraulic parameters } \\
\hline$\theta_{\mathrm{S}}$ & Porosity & & 0.585 & Li et al. (2009) \\
\hline$\theta_{\mathrm{r}}$ & Residual soil water content & & 0.017 & Li et al. (2009) \\
\hline$K_{\text {surface }}$ & Saturated hydraulic conductivity for soil surface & $\mathrm{mm} / \mathrm{h}$ & 4.4 & Optimization \\
\hline$f$ & Hydraulic conductivity decay factor & & -1.84 & Optimization \\
\hline$\alpha$ & van Genuchten parameter & & 0.1 & Optimization \\
\hline$n$ & van Genuchten parameter & & 2.1 & Optimization \\
\hline anik & Hydraulic conductivity anisotropy ratio & & 22.4 & Optimization \\
\hline$K_{\mathrm{G} 0}$ & Groundwater hydraulic conductivity without considering frozen soil & $\mathrm{mm} / \mathrm{h}$ & 1.0 & Optimization \\
\hline \multicolumn{5}{|c|}{ Frozen soil parameters } \\
\hline$d_{\mathrm{s}}$ & Effective depth that feels the diurnal change of temperature & $\mathrm{m}$ & 0.6 & Li et al. (2009) \\
\hline$a$ & empirical coefficient & & 0.0616 & Optimization \\
\hline$b$ & empirical coefficient & & -0.5133 & Optimization \\
\hline
\end{tabular}
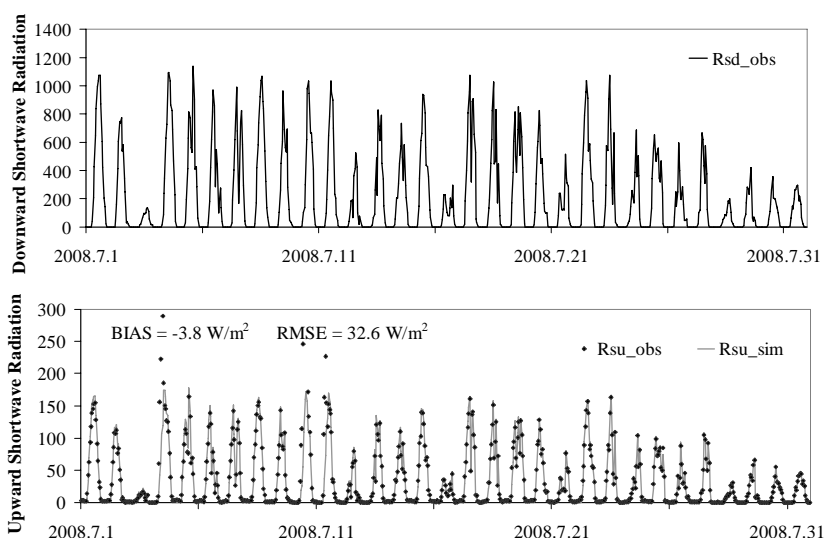

Fig. 4. Simulated and observed hourly upward shortwave radiation (unit: $\mathrm{W} \mathrm{m}^{-2}$ ) at the DY station in July 2008, by using the WEBDHM without the frozen scheme.

$\operatorname{RMSE}=\sqrt{\sum_{i=1}^{N}\left(x_{\mathrm{si}}-x_{\mathrm{oi}}\right)^{2} / N}$,

where $x_{\mathrm{oi}}$ is the observation, $x_{\mathrm{si}}$ is the simulation, and $N$ is the total number of time series for comparison.

Figure 4 shows the simulated and observed hourly upward solar radiation from 1 to 31 July 2008 at DY station with the BIAS and the RMSE, by using the WEB-DHM without the frozen scheme. The observed soil moisture and temperature profiles were used to initialize the model at the first hour of 1 July 2008; while the initial water table depth was assumed as same as the initial depth of the unsaturated zone $(D s=1.25 \mathrm{~m})$. After the calibration of the soil reflectance to visible radiation, the diurnal cycles of the upward solar radiation are well represented by the calibrated WEB-DHM without the frozen scheme. The BIAS and RMSE for the simulated upward shortwave radiation at the DY station are $-3.8 \mathrm{~W} \mathrm{~m}^{-2}$ and $32.6 \mathrm{~W} \mathrm{~m}^{-2}$, respectively. It should be mentioned that the measurements of upward longwave radiation in the station were found erroneous for all periods, and was not used for model evaluation in the study.

Figure 5 illustrates the hourly evolutions of precipitation and the simulated and observed hourly volumetric liquid soil moisture at 5, 10, 20, 40, 80, and $120 \mathrm{~cm}$ in July 2008 at the DY station, by using the WEB-DHM without the frozen scheme. Reasonable responses of soil moisture at the upper layers $(5,10$, and $20 \mathrm{~cm})$ to the rainfall events are reproduced with high accuracies (Fig. 5b-d). The BIAS for the simulated soil moistures at 5,10 , and $20 \mathrm{~cm}$ are $-0.003,0.011$, and -0.012; while their RMSE values are 0.031, 0.029 and 0.030 , respectively. The soil moisture at $120 \mathrm{~cm}$ is also accurately simulated by the WEB-DHM without the frozen scheme (see Fig. 5g), since the soil at this depth was still in frozen in July at the station. The RMSE values for the 

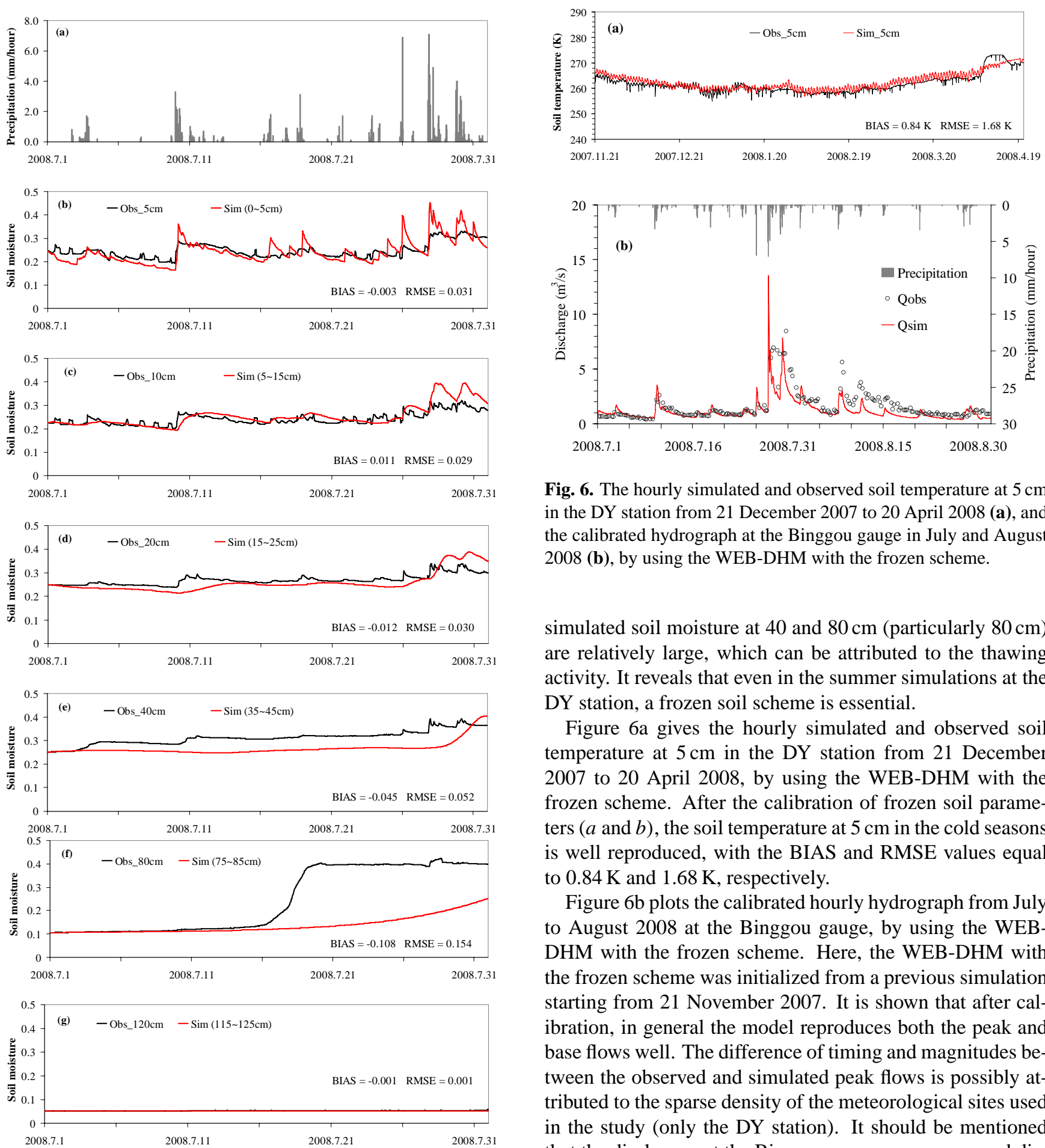

Fig. 6. The hourly simulated and observed soil temperature at $5 \mathrm{~cm}$ in the DY station from 21 December 2007 to 20 April 2008 (a), and the calibrated hydrograph at the Binggou gauge in July and August 2008 (b), by using the WEB-DHM with the frozen scheme.

simulated soil moisture at 40 and $80 \mathrm{~cm}$ (particularly $80 \mathrm{~cm}$ ) are relatively large, which can be attributed to the thawing activity. It reveals that even in the summer simulations at the DY station, a frozen soil scheme is essential.

Figure 6a gives the hourly simulated and observed soil temperature at $5 \mathrm{~cm}$ in the DY station from 21 December 2007 to 20 April 2008, by using the WEB-DHM with the frozen scheme. After the calibration of frozen soil parameters $(a$ and $b)$, the soil temperature at $5 \mathrm{~cm}$ in the cold seasons is well reproduced, with the BIAS and RMSE values equal to $0.84 \mathrm{~K}$ and $1.68 \mathrm{~K}$, respectively.

Figure $6 \mathrm{~b}$ plots the calibrated hourly hydrograph from July to August 2008 at the Binggou gauge, by using the WEBDHM with the frozen scheme. Here, the WEB-DHM with the frozen scheme was initialized from a previous simulation starting from 21 November 2007. It is shown that after calibration, in general the model reproduces both the peak and base flows well. The difference of timing and magnitudes between the observed and simulated peak flows is possibly attributed to the sparse density of the meteorological sites used in the study (only the DY station). It should be mentioned that the discharges at the Binggou gauge were measured discontinuously and irregularly, and thereby the evaluation criterions (e.g., the Nash-Sutcliffe model efficiency coefficient (Nash and Sutcliffe, 1970) and the bias error are not estimated.

Fig. 5. Hourly precipitation (a), and the simulated and observed hourly volumetric liquid soil moisture at 5, 10, 20, 40, 80, and $120 \mathrm{~cm}$ (b-g) at the DY station in July 2008, by using the WEBDHM without the frozen scheme. 


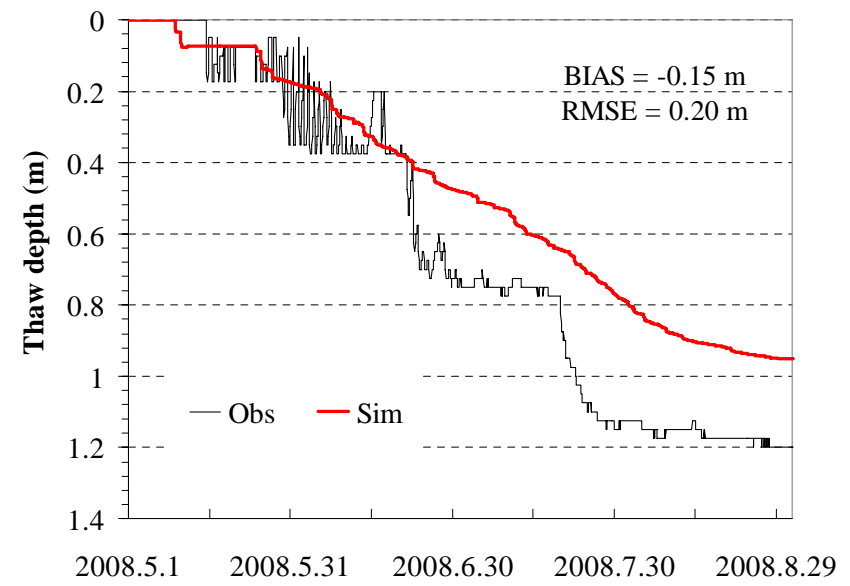

Fig. 7. Hourly observed (interpolated from the observations of soil temperature profile) and simulated thaw depth at the DY station, from 1 May to 31 August 2008, by using the WEB-DHM with the frozen scheme.
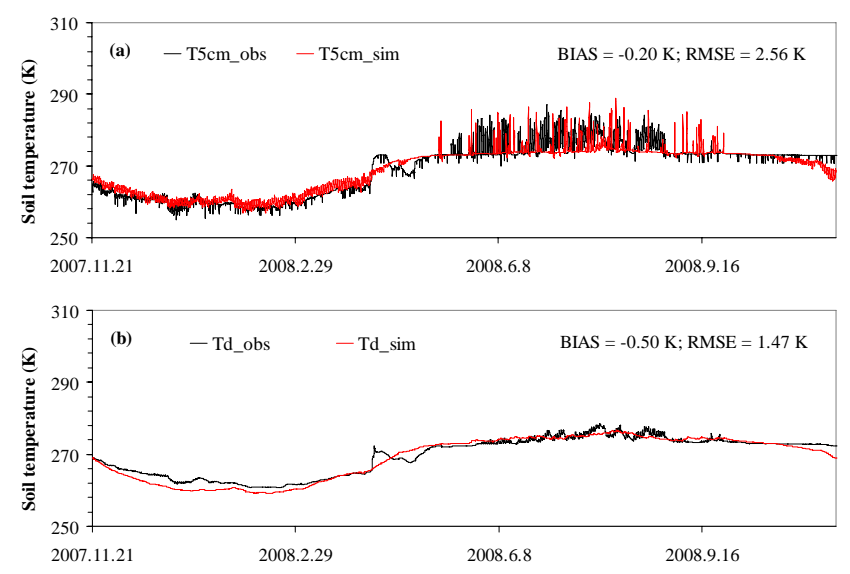

Fig. 8. Hourly observed and simulated temperature at $5 \mathrm{~cm} T_{5 \mathrm{~cm}}$ (a) and temperature of deep soil $T_{\mathrm{d}}$ (b) at the DY station, from 21 November 2007 to 20 November 2008 by using the WEB-DHM with the frozen scheme.

\subsection{Model validation}

The calibrated WEB-DHM with the frozen scheme was then used for a yearlong simulation from 21 November 2007 to 20 November 2008, to check its performance.

\subsubsection{Thaw depth at the DY station from 1 May to 31 August 2008}

Figure 7 displays the hourly observed (interpolated from the observations of soil temperature profile) and simulated thaw depth at the DY station, from 1 May to 31 August 2008, by using the WEB-DHM with the frozen scheme. It is shown that in general the model estimates the thaw depth with an acceptable accuracy, with the BIAS and RMSE values equal to $-0.15 \mathrm{~m}$ and $0.20 \mathrm{~m}$, respectively.
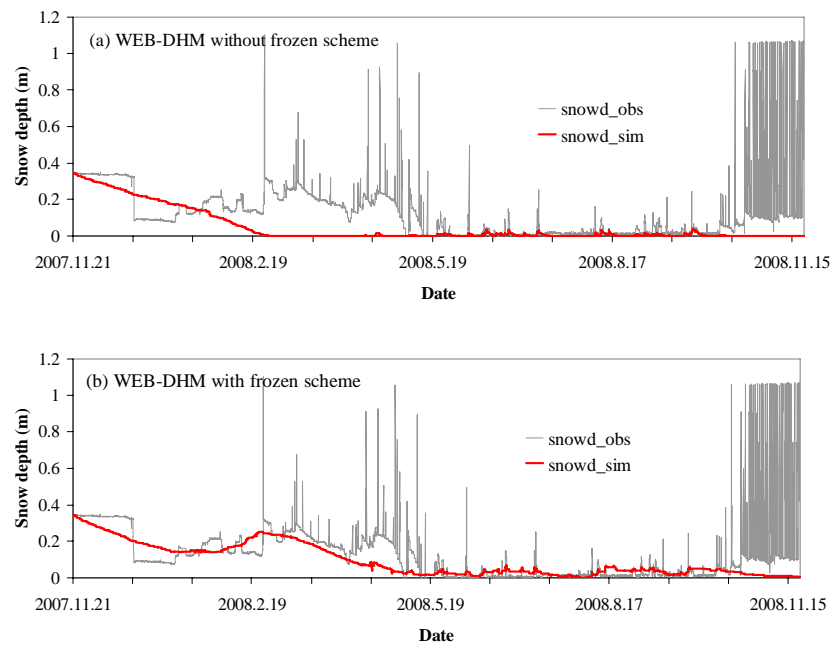

Fig. 9. Hourly snow depth at the DY station from 21 November 2007 to 20 November 2008, simulated by the WEB-DHM without and with the frozen scheme. Here, the snow depth is assumed as five times of the snow-water equivalent, and the large fluctuations of the observed snow depth at the station were caused by strong wind blowing.

\subsubsection{Soil temperature at the DY station from 21 November 2007 to 20 November 2008}

Figure $8 \mathrm{a}$ gives the hourly observed and simulated $T_{\text {soil, }} D_{1}$ from 21 November 2007 to 20 November 2008 at the DY station, by using the WEB-DHM with the frozen scheme. Figure $8 \mathrm{~b}$ plots the hourly simulated $T_{\mathrm{d}}$ by the WEB-DHM with the frozen scheme, comparing to the average of soil temperature at 20,40, and $80 \mathrm{~cm}$. In general, the WEB-DHM with the frozen scheme well reproduces the yearlong $T_{\text {soil, } D_{1}}$ and $T_{\mathrm{d}}$, with the BIAS of $-0.20 \mathrm{~K}$ and $-0.50 \mathrm{~K}$, and the RMSE of $2.56 \mathrm{~K}$ and $1.47 \mathrm{~K}$ for $T_{\text {soil, } D_{1}}$ and $T_{\mathrm{d}}$, respectively.

\subsubsection{Snow depth at the DY station from 21 November 2007 to 20 November 2008}

Figure 9 compares the hourly snow depth at the DY station from 21 November 2007 to 20 November 2008, simulated by the WEB-DHM without and with the frozen scheme. Here, the snow depth is assumed as five times of the snow-water equivalent, and the large fluctuations of the observed snow depth at the station were caused by the strong wind blowing. It is obvious that the WEB-DHM with the frozen scheme predicts the snow depth much better than the WEB-DHM without the frozen scheme.

\subsubsection{Soil moisture at the DY station from 21 November 2007 to 20 November 2008}

Figure 10 draws the hourly volumetric liquid soil moisture averaged at surface layer $(0-5 \mathrm{~cm})$, root zone $(5-25 \mathrm{~cm})$, and deep soil layer $(25-125 \mathrm{~cm})$ at the DY station from 21 
(a) WEB-DHM without frozen scheme
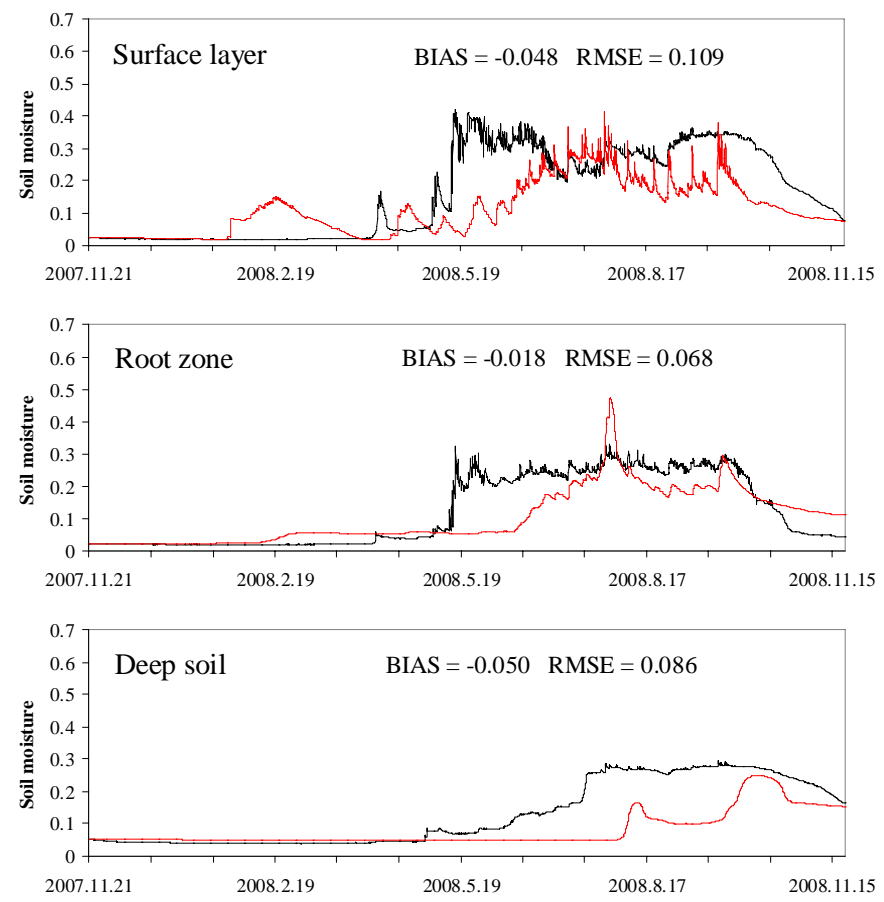

(b) WEB-DHM with frozen scheme
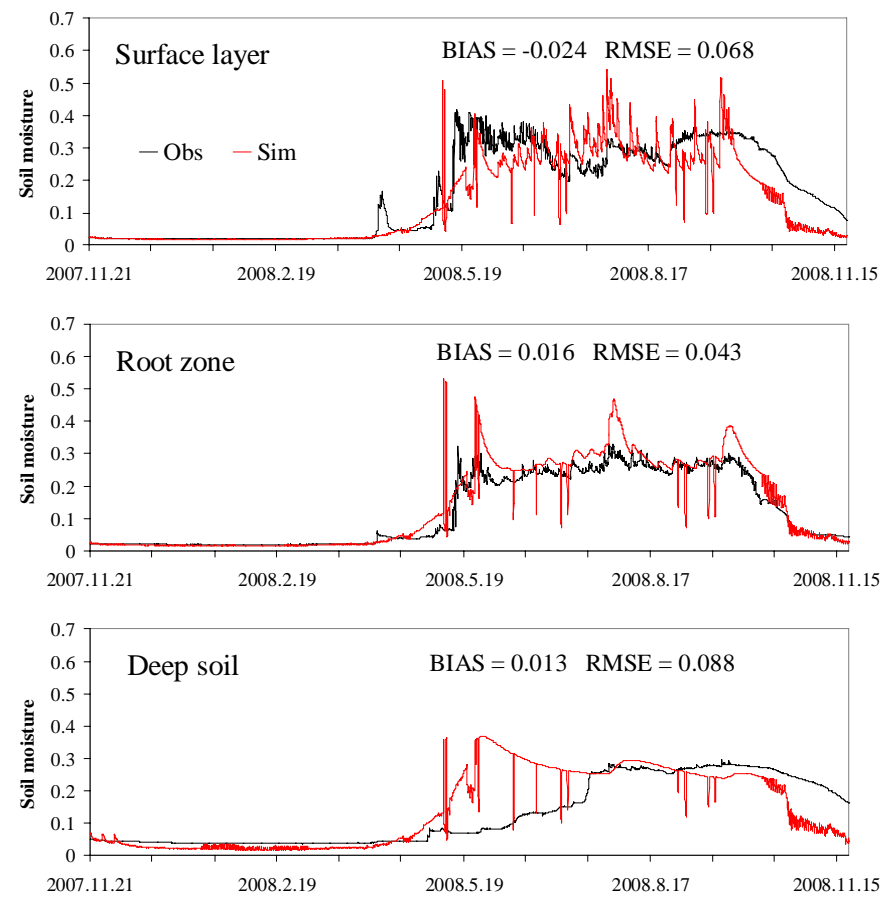

Fig. 10. Hourly volumetric liquid soil moisture averaged at surface layer $(0-5 \mathrm{~cm})$, root zone $(5-25 \mathrm{~cm})$, and deep soil layer $(25-125 \mathrm{~cm})$ at the DY station from 21 November 2007 to 20 November 2008, simulated by the WEB-DHM without and with the frozen scheme.
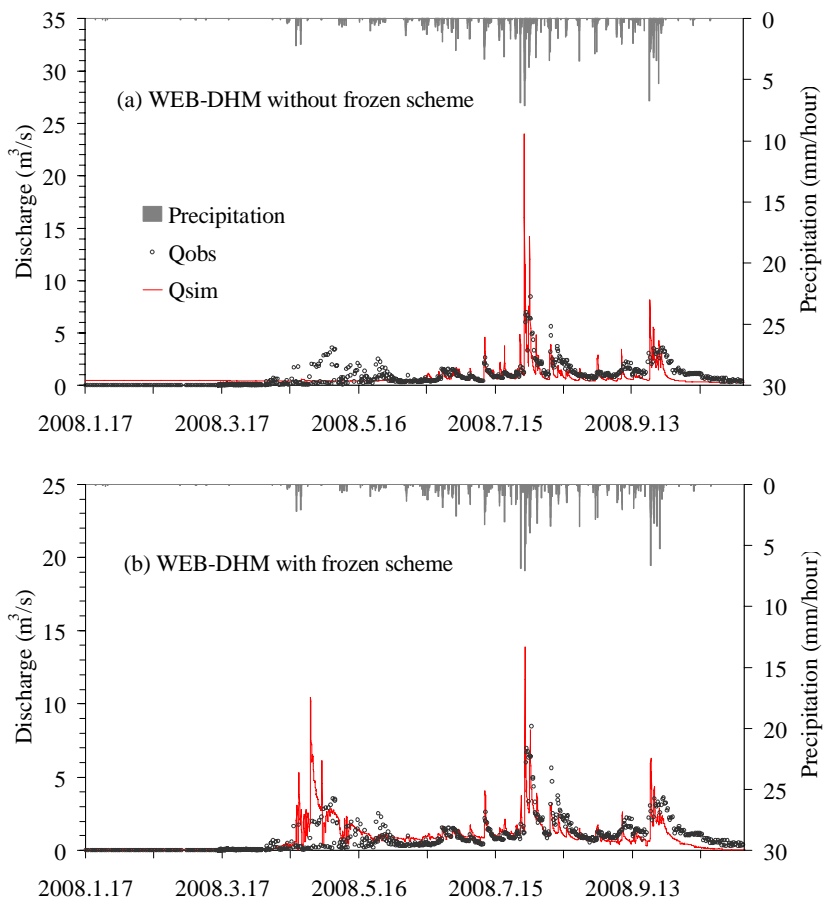

Fig. 11. Linear hourly hydrographs simulated by the WEB-DHM without and with the frozen scheme at the Binggou gauge from 17 January to 20 November 2008 .
November 2007 to 20 November 2008, simulated by the WEB-DHM without and with the frozen scheme. Results showed that the WEB-DHM with the frozen scheme generally gives more realistic yearlong (in particular the thawing periods) soil moisture profile than those simulated by the WEB-DHM without the frozen scheme. For the soil moisture at surface layer $(0-5 \mathrm{~cm})$, root zone $(5-25 \mathrm{~cm})$, and deep soil layer $(25-125 \mathrm{~cm})$, the results by the WEB-DHM with the frozen scheme obtains the RMSE of 0.068, 0.043, and 0.088 , respectively; while the ones by the WEB-DHM without the frozen scheme gets the RMSE of 0.109, 0.068, and 0.086 , respectively. The overestimation of soil moisture at deep soil layer $(25-125 \mathrm{~cm})$, from May to July 2008 by the WEB-DHM with the frozen scheme is possibly attributed to the large gravels distributed in deep soil layers. Without considering the large gravels, the excessive recharges to the deep soil layer from the unconfined aquifer may have been simulated with the WEB-DHM with the frozen scheme. The noises in the simulated liquid soil moistures are caused by the changes of the soil temperatures from below freezing to above freezing.

\subsubsection{Discharges at the Binggou gauge from 17 January to 20 November 2008}

By using the measured streamflows from 17 January to 20 November 2008, the simulated longterm (including cold 

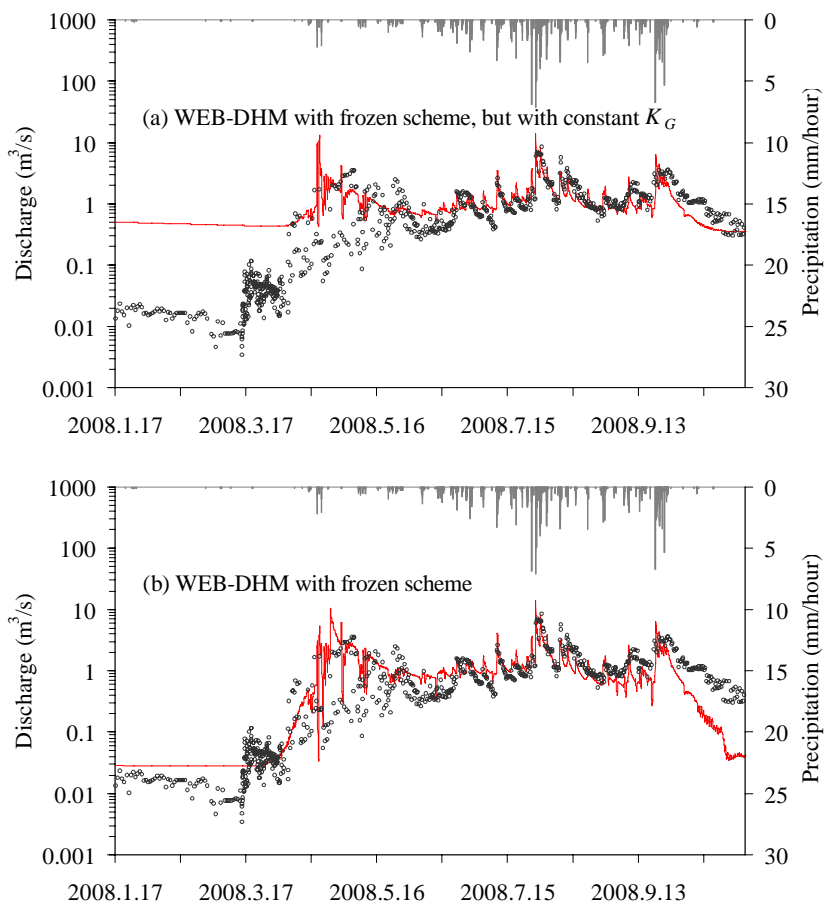

Fig. 12. Logarithmic hourly hydrographs simulated by using the WEB-DHM with the frozen scheme, neglecting (a) and considering (b) the frozen soil effect on the groundwater hydraulic conductivity at the Binggou gauge from 17 January to 20 November 2008.

seasons) hourly discharges at Binggou gauge are further evaluated.

Figure 11 displays the hourly hydrographs simulated by the WEB-DHM without and with the frozen scheme at the Binggou gauge from 17 January to 20 November 2008. Results show that the streamflows simulated by the WEB-DHM with the frozen scheme agree fairly well with the observations; while those calculated by the WEB-DHM without the frozen scheme have large difference from the observations, with the overestimation of baseflows (January-April), the underestimation of snowmelt flows (April-May), and the overestimation of peak flows (July-August). The improved simulation results by the WEB-DHM with the frozen scheme can be attributed to the following reasons:

1. The consideration of reduction factor of the groundwater hydraulic conductivity $\left(f_{\text {ice }, \mathrm{G}}\right)$ largely improves the model's performance from January to April (also see Fig. 12). Figure $12 \mathrm{~b}$ demonstrates the logarithmic hourly hydrographs simulated by using the WEB-DHM with the frozen scheme at the Binggou gauge from 17 January to 20 November 2008, which further confirms the good performance of the new system in simulating base flows. Without the treatments of the frozen soil effect on the groundwater hydraulic conductivity, excessive baseflows have been obtained from January to April 2008 (see Fig. 12a).
2. In the spring season (April-May), more snowmelt runoff calculated by the WEB-DHM with the frozen scheme is due to the treatments of the hydraulic conductivity reduction for each soil layer $\left(f_{\text {ice, } j}\right)$ as a function of soil temperature, which has resulted in less infiltration during the snow melting.

3. The poorer flood peaks obtained by the WEB-DHM without the frozen scheme, are possibly caused by the overestimation of the soil hydraulic conductivities at the deep soil layer and the unconfined aquifer during the thawing process.

\section{Concluding remarks}

In this study, the distributed biosphere hydrological model WEB-DHM was improved by incorporating a frozen soil parameterization. The WEB-DHM with the frozen scheme was then applied to the Binggou watershed for evaluation using the in-situ observations from WATER.

After calibrating land surface parameters, soil hydraulic parameters, and frozen soil parameters, the WEB-DHM with the frozen scheme was then used for a yearlong validation from 21 November 2007 to 20 November 2008, to check the model's applicability in the continuous simulation. Results show that the WEB-DHM with the frozen scheme has given much better performance than the WEB-DHM without the frozen scheme, in the simulations of soil moisture profile at the DY station and the discharges (base and peak flows as well as snowmelt runoff) at the basin outlet in the yearlong simulation.

In the literatures regarding to the frozen soil parameterization in land surface modeling, there are mainly three ways to simulate the ice content or the unfrozen water content within the soil. These methods estimate the ice content depending on the heat available (e.g., Slater et al., 1998; Takata and Kimoto, 2000; Dai et al., 2003), or using the freezing point depression equation (e.g., Koren et al., 1999; Smirnova et al., 2000; Niu and Yang, 2006; Zhang et al., 2007), or relying on empirical equations (Pauwels and Wood, 1999; Li and Koike, 2003). The empirical equations-based frozen soil parameterization by Li and Koike (2003) is used in the study, to improve the original WEB-DHM for simulating frozen soil dynamics, largely due to its simple structure and low computation costs. Furthermore, the study by Li and Koike (2003) has shown the good compatibility between the empirical frozen soil parameterization and $\mathrm{SiB} 2$; while the original WEB-DHM uses a hydrologically-improved SiB2 (Wang et al., 2009c) as its land surface submodel. Although the method in the study estimates the ice content based on empirical equations, the calibrated WEB-DHM with the frozen scheme has demonstrated acceptable accuracies in simulating point-scale frozen soil dynamics and basin-scale integrated streamflows. Meanwhile, the frozen scheme using empirical equations also results in difficulty in achieving an 
optimal set of the frozen soil parameters $a$ and $b$, as the new model (the WEB-DHM with the frozen scheme) is very sensitive to the two parameters (particularly $b$ ) in simulating the soil temperature and moisture profiles.

Different from Li and Koike (2003) that formulated frozen soil process in a 1-D land surface model ( $\mathrm{SiB} 2)$, this study has modified and incorporated the frozen soil scheme into a distributed biosphere hydrological model (WEB-DHM). The newly-developed WEB-DHM with the frozen scheme has made it possible to simulate the basin-scale cold-region land surface hydrological processes in a spatially-distributed manner while considering the topographically-driven lateral flows. It can be used as a model operator in the catchmentscale land surface hydrological data assimilation system in cold regions, to improve modelling of soil moisture and the surface energy budget as well as streamflows.

\section{Appendix A}

\section{Nomenclature}

\begin{tabular}{|c|c|}
\hline Symbol & Definition \\
\hline$C_{\mathrm{d}}$ & $\begin{array}{l}\text { effective heat capacity for the snow-free soil } \\
\left(\mathrm{J} \mathrm{m}^{-2} \mathrm{~K}^{-1}\right)\end{array}$ \\
\hline$C_{\mathrm{g}}$ & $\begin{array}{l}\text { effective heat capacity for the soil surface } \\
\left(\mathrm{J} \mathrm{m}^{-2} \mathrm{~K}^{-1}\right)\end{array}$ \\
\hline$C_{\text {soil }}$ & volumetric heat capacity of soil $\left(\mathrm{J} \mathrm{m}^{-3} \mathrm{~K}^{-1}\right)$ \\
\hline$C_{\mathrm{w}}$ & $\begin{array}{l}\text { volumetric heat capacity of water } \\
\left(\mathrm{J} \mathrm{m}^{-3} \mathrm{~K}^{-1}\right)\end{array}$ \\
\hline$d_{\mathrm{s}}$ & $\begin{array}{l}\text { effective depth that feels the diurnal change } \\
\text { of temperature }(\mathrm{m})\end{array}$ \\
\hline$E_{\mathrm{g}}$ & bare soil evaporation rate $\left(\mathrm{kg} \mathrm{m}^{-2} \mathrm{~s}^{-1}\right)$ \\
\hline$f$ & hydraulic conductivity decay factor \\
\hline$f_{\text {ice }, \mathrm{G}}$ & $\begin{array}{l}\text { reduction factor for the groundwater hy- } \\
\text { draulic conductivity }\end{array}$ \\
\hline$f_{\text {ice }, j}$ & $\begin{array}{l}\text { hydraulic conductivity reduction factor for } \\
\text { the } j \text {-th soil layer }\end{array}$ \\
\hline$H_{\mathrm{g}}$ & sensible heat flux from soil surface $\left(\mathrm{W} \mathrm{m}^{-2}\right)$ \\
\hline$H_{\mathrm{s}}$ & $\begin{array}{l}\text { soil thermal conductivity without considering } \\
\text { frozen soil }\end{array}$ \\
\hline$H_{\mathrm{s}, \text { new }}$ & $\begin{array}{l}\text { soil thermal conductivity considering frozen } \\
\text { soil }\end{array}$ \\
\hline$K_{\mathrm{G}}$ & groundwater hydraulic conductivity $\left(\mathrm{m} \mathrm{s}^{-1}\right)$ \\
\hline$K_{\mathrm{G} 0}$ & $\begin{array}{l}\text { constant groundwater hydraulic conductivity } \\
\text { without considering frozen soil effect }\left(\mathrm{m} \mathrm{s}^{-1}\right)\end{array}$ \\
\hline$K_{j}$ & $\begin{array}{l}\text { soil hydraulic conductivity at the } j \text {-th soil } \\
\text { layer }\left(\mathrm{m} \mathrm{s}^{-1}\right)\end{array}$ \\
\hline$K_{\text {sat }, j}$ & $\begin{array}{l}\text { saturated hydraulic conductivity for the } j \text {-th } \\
\text { soil layer }\left(\mathrm{m} \mathrm{s}^{-1}\right)\end{array}$ \\
\hline$K_{\text {surface }}$ & $\begin{array}{l}\text { saturated conductivity at the soil surface } \\
\left(\mathrm{m} \mathrm{s}^{-1}\right)\end{array}$ \\
\hline$L_{\mathrm{f}}$ & latent heat of fusion $\left(\mathrm{J} \mathrm{kg}^{-1}\right)$ \\
\hline
\end{tabular}

\begin{tabular}{|c|c|}
\hline$M_{\mathrm{gw}}$ & soil interception of liquid store (m) \\
\hline$M_{\mathrm{gs}}$ & snow-ice stored on the ground (m) \\
\hline$n$ & $\begin{array}{l}\text { empirical parameter in van Genuchten's } \\
\text { equation }\end{array}$ \\
\hline$R n_{\mathrm{g}}$ & $\begin{array}{l}\text { absorbed net radiation by soil surface } \\
\left(\mathrm{W} \mathrm{m}^{-2}\right)\end{array}$ \\
\hline$T_{\mathrm{B}}$ & temperature of the bottom soil layer $(\mathrm{K})$ \\
\hline$T_{\mathrm{d}}$ & temperature of the deep soil $(\mathrm{K})$ \\
\hline$T_{\mathrm{f}}$ & freezing point of water $(\mathrm{K})$ \\
\hline$T_{\mathrm{g}}$ & soil surface temperature $(\mathrm{K})$ \\
\hline$T_{\text {soil }, D_{1}}$ & soil temperature at $5 \mathrm{~cm}(\mathrm{~K})$ \\
\hline$T_{\text {Soil }, j}$ & soil temperature at the $j$-th soil layer $(\mathrm{K})$ \\
\hline$T_{\text {soil }, z}$ & soil temperature at a given depth $z(\mathrm{~K})$ \\
\hline \multicolumn{2}{|c|}{ Greek letters } \\
\hline$\alpha$ & $\begin{array}{l}\text { empirical parameters in van Genuchten's } \\
\text { equation }\end{array}$ \\
\hline$\zeta_{\mathrm{f}}$ & frost depth (m) \\
\hline$\zeta_{\mathrm{t}}$ & thaw depth $(\mathrm{m})$ \\
\hline$\theta_{\text {ice }, j}$ & ice content of the $j$-th soil layer $\left(\mathrm{m}^{3} \mathrm{~m}^{-3}\right)$ \\
\hline$\theta_{j}$ & $\begin{array}{l}\text { total volumetric water content of the } j \text {-th soil } \\
\text { layer }\left(\mathrm{m}^{3} \mathrm{~m}^{-3}\right)\end{array}$ \\
\hline$\theta_{\text {liq }, j}$ & $\begin{array}{l}\text { liquid water content of the } j \text {-th soil layer } \\
\left(\mathrm{m}^{3} \mathrm{~m}^{-3}\right)\end{array}$ \\
\hline$\theta_{\mathrm{r}}$ & residual soil water content $\left(\mathrm{m}^{3} \mathrm{~m}^{-3}\right)$ \\
\hline$\theta_{\mathrm{s}}$ & porosity $\left(\mathrm{m}^{3} \mathrm{~m}^{-3}\right)$ \\
\hline$\lambda$ & latent heat of vaporization $\left(\mathrm{J} \mathrm{kg}^{-1}\right)$ \\
\hline$\xi_{\mathrm{gs}}$ & $\begin{array}{l}\text { energy transfer due to phase changes in snow } \\
\text { on ground }\left(\mathrm{W} \mathrm{m}^{-2}\right)\end{array}$ \\
\hline$\rho_{\text {ice }}$ & density of ice $\left(\mathrm{kg} \mathrm{m}^{-3}\right)$ \\
\hline$\rho_{\text {liq }}$ & density of liquid water $\left(\mathrm{kg} \mathrm{m}^{-3}\right)$ \\
\hline$\psi_{j}$ & soil matric potential at the $j$-th soil layer \\
\hline
\end{tabular}

Acknowledgements. This study was funded by grants from Japan Aerospace Exploration Agency. Parts of this work were also supported by grants from the Ministry of Education, Culture, Sports, Science and Technology of Japan. The data used in the paper are provided by the Chinese Academy of Sciences Action Plan for West Development Program (grant number: KZCX2XB2-09) and Chinese State Key Basic Research Project (grant number: 2007CB714400). The fifth author (H. Li) was supported by National Natural Science Foundation of China (grant number: 40671040).

Edited by: W. Wagner

\section{References}

Beven, K. J.: On subsurface storm flow: an analysis of response times, Hydrol. Sci. J., 4, 505-519, 1982.

Bonan, G.: A land surface model (LSM version 1.0) for ecological, hydrological, and atmospheric studies: technical description and user's guide, NCAR Technical Note 417, NCAR, Boulder Co., USA, 1996. 
Cabral, M. C., Garrote, L., Bras, R. L., and Entekhabi, D.: A kinematic model of infiltration and runoff generation in layered and sloped soils, Adv. Water Resour., 15, 311-324, 1992.

Cherkauer, K. A. and Lettenmaier, D. P.: Hydrologic effects on frozen soils in the upper Mississippi River basin, J. Geophys. Res., 104(D16), 19599-19610, 1999.

Dai, Y., Zeng, X., Dickinson, R. E., et al.: The Common Land Model, B. Am. Meteorol. Soc., 84, 1013-1023, 2003.

Deardorff, J. W.: Efficient prediction of ground surface temperature and moisture, with inclusion of a layer of vegetation, J. Geophys. Res., 83, 1889-1903, 1977.

FAO: Digital soil map of the world and derived soil properties, Land and Water Digital Media Series Rev. 1, United Nations Food and Agriculture Organization, CD-ROM, 2003.

Gao, Y., Chen F., Barlage, M., et al.: Enhancement of land surface information and its impact on atmospheric modeling in the Heihe River Basin, northwest China, J. Geophys. Res., 113, D20S90, doi:10.1029/2008JD010359, 2008.

Kane, D. L. and Stein, J.: Water Movement Into Seasonally Frozen Soils, Water Resour. Res., 19(6), 1547-1557, 1983.

Koren, V., Schaake, J., Mitchell, K., Duan, Q., Chen, F., and Baker, J.: A parameterization of snowpack and frozen ground intended for NCEP weather and climate models, J. Geophys. Res., 104(D16), 19569-19585, 1999.

Li, S. and Cheng, G.: Problem of Heat and Moisture Transfer in Freezing and Thawing Soils. Lanzhou Univ. Press, Lanzhou, China, 203 pp, 1995.

Li, X. and Koike, T.: Frozen soil parameterization in SiB2 and its validation with GAME-Tibet observations, Cold Reg. Sci. Technol., 36, 165-182, 2003.

Li, X., Ma, M. G., Wang, J., Liu, Q., Che, T., Hu, Z. Y., Xiao, Q., Liu, Q. H., Su, P. X., Chu, R. Z., Jin, R., Wang, W. Z., and Ran, Y. H.: Simultaneous remote sensing and ground-based experiment in the Heihe River Basin: Scientific objectives and experiment design, Adv. Earth Sci., 23, 897-914, 2008.

Li, X., Li, X. W., Li, Z. Y., Ma, M. G., Wang, J., Xiao, Q., Liu, Q., Che, T., Chen, E. X., Yan, G. J., Hu, Z. Y., Zhang, L. X., Chu, R. Z., Su, P. X., Liu, Q. H., Liu, S. M., Wang, J. D., Niu, Z., Chen, Y., Jin, R., Wang, W. Z., Ran, Y. H., Xin, X. Z., and Ren, H. Z.: Watershed Allied Telemetry Experimental Research, J. Geophys. Res., 114, D22103, doi:10.1029/2008JD011590, 2009.

Luo, L., Robock, A., Vinnikov, K. Y., et al.: Effects of frozen soil on soil temperature, spring infiltration, and runoff: results from the PILPS 2(d) experiments at Valdai, Russia, J. Hydrometeorol., 4, 334-351, 2003.

Luo, S., Lü, S., and Zhang, Y.: Development and validation of the frozen soil parameterization scheme in Common Land Model, Cold Reg. Sci. Technol., 55, 130-140, 2009.

Myneni, R. B., Nemani, R. R., and Running, S. W.: Algorithm for the estimation of global land cover, LAI and FPAR based on radiative transfer models, IEEE. T. Geosci. Remote, 35, 13801393, 1997.

Mou, L., Tian, F., Hu, H., and Sivapalan, M.: Extension of the Representative Elementary Watershed approach for cold regions: constitutive relationships and an application, Hydrol. Earth Syst. Sci., 12, 565-585, 2008, http://www.hydrol-earth-syst-sci.net/12/565/2008/.

Nakano, Y., Tice, A. R., and Oliphant, J. L.: Transport of water in frozen soil: I. Experiment determination of soil water diffusiv- ity under isothermal condition, Adv. Water. Resour., 5, 221-226, 1982.

Nash, J. E., and Sutcliffe, J. V.: River flow forecasting through conceptual models part I - A discussion of principles, J. Hydrol., 10(3), 282-290, 1970.

Nicolsky, D. J., Romanovsky, V. E., Alexeev, V. A., and Lawrence, D. M.: Improved modeling of permafrost dynamics in a GCM land-surface scheme, Geophys. Res. Lett., 34, L08501, doi:10.1029/2007GL029525, 2007.

Niu, G. and Yang, Z.: Effects of frozen soil on snowmelt runoff and soil water storage at a continental scale, J. Hydrometeorol., 7, 937-952, 2006.

Pauwels, V. R. N. and Wood, E. F.: A soil-vegetation-atmosphere transfer scheme for the modeling of water and energy balance processes in high latitudes. 1. Model improvements, J. Geophys. Res., 104, 27811-27822, 1999.

Poutou, E., Krinner, G., Genthon, C., and de Noblet-Ducondré, N.: Role of soil freezing in future boreal climate change, Clim. Dynam., 23, 621-639, 2004.

Robinson, J. S. and Sivapalan, M.: Instantaneous response functions of overland flow and subsurface stormflow for catchment models, Hydrol. Processes, 10, 845-862, 1996.

Romanovsky, V. E. and Osterkamp, T. E.: Effects of unfrozen water on heat and mass transport processes in the active layer and permafrost, Permafrost Periglac. Process., 11, 219-239, 2000.

Sellers, P. J., Randall, D. A., Collatz, G. J., Berry, J. A., Field, C. B., Dazlich, D. A., Zhang, C., Collelo, G. D., and Bounoua, L.: A revised land surface parameterization (SiB2) for atmospheric GCMs, Part I: Model Formulation, J. Climate, 9, 676705, 1996a.

Sellers, P. J., Los, S. O., Tucker, C. J., Justice, C. O., Dazlich, D. A., Collatz, G. J., and Randall, D. A.: A revised land surface parameterization (SiB2) for atmospheric GCMs, Part II: The generation of global fields of terrestrial biosphysical parameters from satellite data, J. Climate, 9, 706-737, 1996b.

Slater, A. G., Pitman, A. J., and Desborough, C. E.: Simulation of freeze-thaw cycles in a general circulation model land surface scheme, J. Geophys. Res., 103(D10), 11303-11312, 1998.

Smirnova, T. G., Brown, J. M., Benjamin, S. G., and Kim, D: Parameterization of cold-season processes in the MAPS landsurface scheme, 105(D3), 4077-4086, 2000.

Stocker-Mittaz, C., Hoelzle, M., and Haeberli, W.: Permafrost distribution modeling based on energy-balance data: a first step, Permafrost Periglacial Processes, 13, 271-282, 2002.

Stull, R. B.: An Introduction to Boundary Layer Meteorology, Kluwer Academic Publishers, The Netherlands, 1988.

Takata, K. and Kimoto, M.: A numerical study on the impact of soil freezing on the continental-scale seasonal cycle, J. Meteor. Soc. Japan, 78, 199-221, 2000.

Tang, Q., Oki, T., Kanae, S., and Hu, H.: Hydrological cycles change in the Yellow River Basin during the last half of the twentieth century, J. Climate, 21, 1790-1806, 2008.

Tian, F., Hu, H., Lei, Z., and Sivapalan, M.: Extension of the Representative Elementary Watershed approach for cold regions via explicit treatment of energy related processes, Hydrol. Earth Syst. Sci., 10, 619-644, 2006 http://www.hydrol-earth-syst-sci.net/10/619/2006/.

The Institute of Geocryology: Siberia Branch, Academy of Soviet Union, General Geocryology, translated by: Guo, D., Liu, T., 
and Zhang, W., 1988. Sciences Press of China, Beijing, 318 pp., 1974.

van Genuchten, M. T.: A closed form equation for predicting the hydraulic conductivity of unsaturated soils, Soil Sci. Soc. Am. J., 44, 892-898, 1980.

Wang, L., Koike, T., Yang, K., Jackson, T., Bindlish, R., and Yang, D.: Development of a distributed biosphere hydrological model and its evaluation with the Southern Great Plains Experiments (SGP97 and SGP99), J. Geophys. Res., 114, D08107, doi:10.1029/2008JD010800, 2009a.

Wang, L., Koike, T., Yang, K., and Yeh, P. J. F.: Assessment of a distributed biosphere hydrological model against streamflow and MODIS land surface temperature in the upper Tone River Basin, J. Hydrol., 377, 21-34, 2009b.

Wang, L., Koike, T., Yang, D., and Yang, K.: Improving the hydrology of the Simple Biosphere Model 2 and its evaluation within the framework of a distributed hydrological model, Hydrol. Sci. J., 54(6), 989-1006, 2009c.

Woo, M., Arain, M. A., Mollinga, M., and Yi, S.: A twodirectional freeze and thaw algorithm for hydrologic and land surface modelling, Geophys. Res. Lett., 31, L12501, doi:10.1029/2004GL019475, 2004.

Yang, Z., Yang, Z., and Zhang, X.: Runoff and its generation model of cold region in Binggou Basin of Qilian Mountain, Memoirs of Lanzhou Institute of Glaciology and geocryology, Chinese Academy of Sciences, 7, 91-99, 1992 (in Chinese).
Yang, Z., Yang, Z., Liang, F., and Wang, Q.: Permafrost hydrological processes in Binggou Basin of Qilian Mountains, J. Glaciol. Geocryol., 15(2), 235-241, 1993 (in Chinese).

Ye, B. S., Yang, D. Q., Zhang, Z. L., and Kane, D.: Variation of hydrological regime with permafrost coverage over Lena Basin in Siberia, J. Geophys. Res., 114, D07102, doi:10.1029/2008JD010537, 2009.

Yershov, E. D.: General geocryology, Cambridge University press, 1990.

Zhang, X., Sun, S., and Xue, Y.: Development and testing of a frozen soil parameterization for cold region studies, J. Hydrometeorol., 8, 690-701, doi:10.1175/JHM605.1, 2007.

Zhang, Z., Kane, D. L., and Hinzman, L. D.: Development and application of a spatially-distributed Arctic hydrological and thermal process model (ARHYTHM), Hydrol. Processes, 14, 10171044, 2000.

Zhang, X. and Yang, Z.: The primary analysis of water balance in in Binggou Basin of Qilian Mountains, J. Glaciol. Geocryol., 13(1), 35-42, 1991 (in Chinese). 